\title{
DE NEDERLANDERS IN DE CARAIBISCHE WATEREN; EEN NABETRACHTING
}

\author{
DOOR
}

\section{W. R. MENKMAN}

Aan mijn besprekingen ${ }^{1}$ ) der Spaansche documenten betreffende de Nederlandsche activiteit in de West van na het Bestand tot den vrede van Munster, verzameld door Miss Wright, vertaald door prof. Van Dam en uitgegeven door het Hist. Gen., blijkt nog wel iets toegevoegd te kunnen worden.

Het heeft mij indertijd getroffen, dat Nederlanders en Spanjaarden zich in de West doorgaans hielden aan de regels van „be„schaafd oorlogvoeren" en dat er zoo weinig onnoodige wreedheden geschiedden. Elders ging het wel eens anders toe.

Zoo wordt in de beschrijving van den vlootaanval op de Canarische eilanden van 1599 (pamfl. verz. Kon. Bibl. Nos. 1106 en 1107) verteld, dat bij de actie op Gran Canaria de vijanden een krijgsgevangene in vieren hieuwen en dat de onzen dat beantwoordden, door met een gevangen Spanjaard (of misschien een inboorling) op dezelfde wijze te werk te gaan.

In het gevecht te water geraakte vijandelijke schepelingen werden in den regel opgevischt en ",geberght"; niet aldus echter bij den aanval der Spaansch-Portugeesche vloot op Nederlandsch Brazilië in den aanvang van 1640 . Dertig man van de vijandelijke vloot, die in het water rondzwommen, werden door de onzen „of "met het stael omgebracht, of in de vloet versmoort". Als excuus voegt de kroniekschrijver (Leeven en Daden der Doorlughtige Zee-Helden, 1683) er bij „dewyl de bitterheyt te groot was”. Twee en drie kwart eeuw later (Baralong Case, Aug. 1915) kon niet eens als verontschuldiging aangevoerd worden, dat een verbitterd gevecht voorafgegaan was.

Een geval van wreedheid en trouweloosheid - van de zijde der

1) W. I. Gids XVII, 7, blz. 193 e.v., W. I. Gids XVIII, 6, blz. 161 e.v. 
Spanjaarden - was dat, aan Wemberich van Berghem overkomen, den lateren vice-admiraal van Holland en West-Friesland (1628); het laatste, dat ik over deze zaak heb kunnen vinden, werd tachtig jaar geleden geschreven ${ }^{1}$ ).

Er heeft onzekerheid bestaan over de plaats waar en het jaar waarin het geval-Van Berghem zich afgespeeld heeft, maar het betrouwbaarst schijnt te zijn het verhaal bij Wassenaer, die het geeft onder Juni 1627, hoewel het van veel vroegeren datum zijn moet en wel, in verband met Wemmer's verdere loopbaan, vóór 1607.

Van B. dan lag met zijn schip ,in de revier Sasso, op 't eylant „Cuba" ${ }^{2}$ ) en werd daar overvallen door een Spaansche „armade” onder den kapitein Juan Adama (een Fries in Spaanschen dienst misschien?). Na een dappere verdediging, blijkbaar tegen een overmacht, besluit Van B. zijn schip in de lucht te laten springen, ,wel wetende wat die overcomt die daer ghecregen wiert”. $\mathrm{Na}$ de ontploffing was niemand meer in leven dan Van B. zelf en de man die de lont in het kruit gestoken had, beiden zwaar gewond, alsmede een kleine jongen. Men kon zich blijkbaar bergen op het andere Nederlandsche schip, waarmede men tezamen op de rivier lag en gaf zich op voorwaarde van lijfsbehoud aan Adama over.

Toen het donker geworden was, bemerkte Van B., dat de Spanjaarden zijn zwaargekwetsten ondergeschikte over boord geworpen hadden, waardoor deze laatste kwam te verdrinken. Natuurlijk protesteerde Van B. er tegen, dat men „soo grouwelijck met „malcanderen” handelde, waarop Adama met de hand aan den degen verzekerde, geen voorkennis van de daad gehad tehebben en zijn woord gestand te zullen doen, desnoods ,in tegenwille van „den paus of de coninck van Spangien".

Adama hield woord; hij nam Van B. bij zich in huis (waar?), doch spoedig eischte de gouverneur de gevangenen op, om hen te laten executeeren. Van B. echter kreeg gelegenheid om uit de gevangenis te ontkomen, blijkbaar met hulp van Adama en van een priester, doch hij moest zich verbinden om, eenmaal in veiligheid, een aanzienlijke som te overhandigen aan den gids, die hem medegegeven werd. De vluchteling wist aan boord terug te komen en betaalde daar zijn losprijs; hoe het mogelijk was dat het andere schip op de rivier met rust gelaten werd en dit Nederlandsche vaartuig (misschien ook dat van Van B. zelf, wanneer het niet

$\left.{ }^{1}\right)$ Mr. J. L. Gregory, Bijdr. Vaderl. Gesch. en Oudheidk. 1e reeks, 10 e deel.

2) Zaza of Saza, Zuidkust, tegenwoordige provincie Santa Clara. 
onherstelbaar beschadigd was) de reis vervolgen kon, blijkt niet.

Van B. had in 1609, toen hij als bevelhebber van een jacht der o. I. Comp. het bericht van het Bestand naar Indië overbracht, gelegenheid om te Lissabon zijn vroegeren tegenstander Adama warm bij den onderkoning aldaar aan te bevelen, uit dankbaarheid tegenover den redder van zijn leven.

Ik heb Wassenaar's verhaal niet met Spaansche gegevens kunnen vergelijken; wellicht is het Miss Wright niet bekend geweest, althans haar artikel in de Hispano-American review van 1921, The Dutch and Cuba, dat ik h.t.l. niet heb kunnen bekomen, behandelt de periode 1609-1641 en het geval Van Berghem moet zich eenige jaren vroeger hebben afgespeeld.

Het heeft indertijd heel lang geduurd, voordat Mr. J. L. Gregory die zich voor den Gelderschman Wemberich (Wilhelm, Wemmer) van Berghem interesseerde, te weten kwam, dat er in Wassenaer's Historisch Verhael het een en ander over zijn held te vinden was; misschien zelfs was het bestaan dezer kroniek, toen nog minder algemeen bekend dan tegenwoordig, hem verborgen gebleven.

Ook thans echter behoort er moed toe, om in Wassenaer te gaan zoeken; een en twintig deeltjes, met gothische letter gedrukt, niet van een goeden index voorzien en soms - zooals inzake Van Berghem - feiten vermeldende, welke vóór den aanvang van het „Verhael” (1621) voorgevallen zijn. Welk een nuttigen arbeid zouden werklooze intellectueelen kunnen verrichten, met, al was het alleen maar indexeeren van den inhoud onzer zeventiende eeuwsche kronieken, om niet te spreken van hetgeen er misschien nog gedaan zou kunnen worden, om de ongedrukte bronnen in onze archieven beter tot haar recht te laten komen.

Nog bij het sluiten van het Bestand meende Spanje, dat het onzerzijds opgeven van den Westindischen handel tot de eventueele vredesvoorwaarden zou kunnen behooren; inderdaad bestond zoodanige handel en werd de Caraibische Zee door de Nederlanders reeds geruimen tijd vóór de oprichting der W. I. Comp. nog om andere redenen bezocht dan om buit te maken, hout te kappen en zout te garen. Wassenaer's relaas, hier boven geciteerd, bewijst het.

Van Berghem was door ,syn meesters” (particuliere kooplieden natuurlijk, immers men schreef 1606 of nog vroeger) „na West „Indien om te negotieren ghesonden”, hij was op Cuba „op de „handelingh" en betaalde later zijn losprijs ten deele ,in coopman„schappen”; een deel der retourlading was kennelijk reeds aan 
boord, want er wordt verteld, dat de man, die het kruit ontstak, „onder de huyden" terecht kwam. Zoowel op Cuba als op Española vond men uitgestrekte gebieden, niet in cultuur en niet meer door Indianen bevolkt, waar jacht gemaakt werd op de verwilderde runderen en varkens (boekaniersbedrijf), waarvan huiden, talk en reuzel hetzij, evenals het vleesch, in de steden verkocht, of aan de kust direct aan koopvaarders geleverd werden, in ruil voor wapenen, ammunitie, kleeren, sterke drank enz.

Natuurlijk waren die vreemde koopvaarders indringers en werd hun handel clandestien gedreven. Zij voorzagen echter in een behoefte en met geld en goede woorden was er van de Spaansche autoriteiten veel gedaan te krijgen. Het avontuur van Van Berghem lijkt op zekere punten op een gewelddadig intermezzo, dat eindigde met een accoord.

$\mathrm{Het}$ is wel vreemd, dat onder de gegeven omstandigheden $\mathrm{Cu}-$ raçao niet heel spoedig na 1634 ook station werd voor den (clandestienen) handel met de vaste kust van Zuid-Amerika, in plaats van enkel een basis voor de krijgsbedrijven, maar daarvan blijkt, zooals ik destijds reeds opmerkte, niets uit de door Miss Wright verzamelde Spaansche documenten; die stukken evenwel waren van Spaansche ambtenaren afkomstig.

Intusschen werd de kaapvaart op West Indië wel gecombineerd met zout en verfhout verzamelen, wanneer de buit geen voldoende retourvracht opleverde; ook kon de kaper tevens koopvaarder zijn. Van Berghem had blijkbaar een kaperbrief, want Van Wassenaer zegt, dat onze held bij zijn thuiskomst door "syn meesteren” geprezen werd als ,een spiegel voor alle die ghene die in commissie „gaen".

In den koopman uit Zeeland, Gaspar Rubergue, die in 1634 met Van Walbeeck meekwam, heb ik destijds een der Middelburgsche Van Rouberges meenen te zien, die bij De Laet (Iaerlyck Verhael) als kaapvaartreeders voorkomen. Hun naam komt ook voor in het Korte Historiael van David Pietersz. de Vries ${ }^{1}$ ).

Deze laatste heeft nogal wat gehoord en gezien van het afloopen door de Spanjaarden van Tortuga in Januari 1635, waarbij volgens een bij Kaap Tiburon ${ }^{2}$ ) ontmoeten Zeeuwschen kaper, Pieter Jansz. Maertman, den zegsman van De Vries, 500-600 Engelschen gedood zouden zijn. Deze Maertman, misschien echter een

1) Het laatst bewerkt door dr. H. T. Colenbrander, Linschoten-Vereeniging 1911.

$\left.{ }^{2}\right)$ Zuidel. deel van het tegenwoordige Haïti. 
beetje blufferig aangelegd evenals De Vries zelf, zou den Engelschen voor nog erger behoed hebben. Ook leverde de kaper een aantal Spaansche gevangenen aan den Engelschen gouverneur uit, met de bedoeling, dat zij tegen gevangen Engelschen uitgewisseld zouden worden; de Engelschen echter hadden, volgens Maertman, de Spanjaarden onmiddellijk om hals gebracht, „daerse niet veel „eer af hadden”, merkt De Vries op, die nogal anti-Engelsch was.

De Vries pikte nog wat gevluchte Engelschen van Tortuga op, die hij bij de Caimites ${ }^{1}$ ) in twee booten aantrof en ging toen in de baai van Goave ${ }^{1}$ ) ververschen, waar hij een boot vond met Spaansch volk, afkomstig van een met huiden geladen Spaansch schip, dat door „Roebergen” genomen was. Op 12 April komt De Vries op het inmiddels weder door de Spanjaarden verlaten Tortuga aan, waar „Roebergen” ligt met zijn prijs, het huidenschip.

In zijn Colonizing expeditions to the West Indies and Guiana $1623^{-1627^{2}}{ }^{2}$ nam Vincent T. Harlow het verhaal op der eerste vestiging op St. Kitts en Nevis ${ }^{3}$ ). John Hilton, die bij de expeditie van Don Fred. de Toledo in 1629 in handen der Spanjaarden geraakt was, ging na vijf jaar gevangenschap, dus in 1634, naar Tortuga om zich daar neer te zetten; hij maakte de reis dâarheen (van Nevis) met een schip van Middelburg, toebehoorend aan „Mijnheer Rueboroe (Rumeboroe, Runeboroe)”, wat wel een verbastering zal zijn van Roubergen.

Volgens de geschiedenis van Curaçao ${ }^{4}$ ) zou er omstreeks 1638 een Frederik Roeberge op Sint Kitts gevestigd geweest zijn.

Het jacht, dat tezamen met dat van Van Berghem op de Sazarivier lag, wordt door Wassenaer genoemd een „Hollantsch jacht, „van Jan Potey en andere uytgheredet”. Het zal echter wel een Zeeuwsch schip geweest zijn, want Pottey is een Zeeuwsche naam. Van de Westindische relaties der Potteys heb ik echter in de bekende bronnen (Smallegange, Pieter de la Ruë, Nagtglas) niets kunnen vinden.

In de geschiedenis van Curaçao ${ }^{5}$ ) komt een zeventiende eeuwsche Pottey voor (Pieter, een militair) en een achttiende eeuwsche (Aldert, secretaris).

$\left.{ }^{1}\right)$ Zuidel. deel van het tegenwoordige Haiti.

2) Hackluyt Society, second series, LVI, 1924.

s) Egerton Mss. 2395, pag. 503/509B Br. Museum.

4) C. P. Amelunxen, blz. 31 .

•) C. P. Amelunxen, blz. 50 en 95. 
In Miss Wright's Spaansche documenten komt hier en daar iets voor over kleurlingen in Nederlandschen dienst; Diego Martin was wel de belangrijkste figuur onder hen.

Thomas Gage, de afvallige Engelsche katholiek, die verondersteld wordt invloed gehad te hebben op het tot stand komen van Cromwell's Western Design, waarvan de verovering van Jamaica in 1655 door Venables en Penn voorloopig het eenige, vrij magere resultaat was, deze Gage heeft in zijn boek ${ }^{1}$ ) het een en ander over den kleurling-kapitein Diego Martin medegedeeld.

Toen Gage, destijds nog Dominikaan, uit Centraal Amerika naar Europa terug wilde keeren, ging zijn reis over Cartagena, waar hij zich inscheepte voor de Westindische eilanden (1637). Dit schip werd op weg naar Porto Bello (Porto Velo op de landengte van Panamá) aangehouden door twee Hollandsche kapers onder kapitein Daguillo, een te Havana geboren mulat, die wegens mishandeling, in Campêche van de Spanjaarden ondervonden, naar de Hollanders overgeloopen en met een Hollandsche gehuwd was. Deze kleurling had onder Houtebeen een commando gekregen.

Gage krijgt gelegenheid naar Cartagena terug te keeren, vanwaar hij na allerlei omzwervingen eindelijk te Havana aankomt, waar hij op de thuisvarende Spaansche vloot van Vera Cruz wacht. Tijdens zijn verblijf te Havana bracht Gage volgens een gedane belofte een bezoek aan de aldaar levende moeder van kapitein Diego.

De knaap, die volgens Wassenaer, met Van Berghem op de Sazarivier na de ontploffing in het leven was gebleven, was „een „Moortjen van twaelf jaren”; of het een negertje of een Turkje was, valt niet uit te maken.

In een der documenten in Nederlandsche Zeevaarders II is sprake van „Turcos”, die als krijgsgevangenen op de Hollandsche schepen dienden; eenige tientallen jaren eerder hadden het zeer goed vrijwillig dienende Turken kunnen zijn. Van de vele Turksche gevangenen, in 1604 door Maurits na de inneming van Sluis bevrijd, trad een deel bij de tegenstanders van Spanje in dienst en in 1612 kwam de eerste capitulatie tot stand tusschen de Republiek en den Sultan. In 1618 echter sloeg David Pietersz de Vries in de Middellandsche Zee een aanval van drie Turksche galeien af, die „op 't vleytighste kwamen aensassen" en, zooals bekend is, heeft onze scheepvaart in de 17e eeuw en later veel te lijden gehad

$\left.{ }^{1}\right)$ Th. Gage, The English American, or a new survey of the West Indies, ed. by A. P. Newton. 
van Barbarijsche, Algerijnsche, Tunesische en Maroccaansche zeeroovers, die echter ook wel door Europeanen (w.o. Nederlanders) aangevoerd werden.

In het eerste deel der Nederlandsche Zeevaarders werd gesproken over Mardique (Mardijk), het fort bij Duinkerken. Misschien is het niet juist, uit De Jonge (Zeewezen) te lezen dat dit fort ook wel het „houten wambuis” genoemd werd. Deze laatste naam werd gegeven aan een palisadeering, zie Dr. P. J. Blok, Het plan tot oprichting eener Compagnie van Assurantie ${ }^{1}$ ) en H. Malo's kaperboek ${ }^{2}$ ).

Waren zulk soort versperringen ook in West Indië gebruikelijk? David Pietersz. de Vries vertelt in zijn Historiael, dat hij op de Bahamas een boschje boomen op een eiland waarnam, dat er van verre uitzag als een fort „ofte een Houte-wanbuis”.

1) Bijdr. Vaderl. Gesch. en Oudheidk. Vierde reeks, Dl. I.

$\left.{ }^{2}\right)$ Les Corsaires dunkerquois etc. Dl. I. 